\title{
Small cell carcinoma of the bladder
}

\author{
Carcinoma de células pequenas de bexiga \\ Bruno Nagel Calado ${ }^{1}$, Paulo Eduardo Goulart Maron², Bruno César Vedovato ${ }^{1}$, Tomas Zecchini Barrese², \\ Roni de Carvalho Fernandes ${ }^{2}$, Marjo Deninson Cardenuto Perez ${ }^{2}$
}

\begin{abstract}
Small cell carcinoma of the urinary bladder is an extremely aggressive and rare tumor. Even though small cell carcinoma most commonly arises from the lungs there are several reports of small cell carcinoma in extrapulmonary sites. Due to its low frequency there is no well-established management for this disease. We report the case of a 61 year-old man with small cell carcinoma of the bladder who underwent radical cystectomy following neoadjuvant chemotherapy. We also reviewed the literature for the optimal treatment strategy.
\end{abstract}

Keywords: Urinary bladder neoplasms/drug therapy; Carcinoma, small cell/drug therapy; Cystectomy/methods; Case reports

\section{RESUMO}

0 carcinoma de células pequenas da bexiga urinária é um tumor extremamente agressivo e raro. Apesar desses tumores terem como sítio principal o pulmão, existem diversos relatos de carcinoma de pequenas células extrapulmonares. Pela baixa frequência, ainda não existe um tratamento bem estabelecido para essa neoplasia. Relatamos o caso de um homem de 61 anos de idade com carcinoma de células pequenas da bexiga urinária que foi submetido à quimioterapia neoadjuvante seguida de cistectomia radical. Fazemos ainda revisão na literatura em busca dos métodos de maior sucesso para o tratamento.

Descritores: Neoplasias da bexiga urinária/quimioterapia; Carcinoma de células pequenas/quimioterapia; Cistectomia/métodos; Relatos de casos

\section{INTRODUCTION}

Small cell carcinoma of the bladder is a very rare and aggressive histological subtype, and accounts for less than $1 \%$ of all bladder tumors. ${ }^{(1)}$ Its management is challenging because it presents in the same way of other more frequent histological types, but with a high metastatic power. The diagnosis demands that the pathologist be suspicious and accurate in the analysis of the fragments of a transurethral bladder resection (TUR). Multimodal treatment, including radical cystectomy, chemotherapy and radiation therapy should be initiated as soon as possible for a chance of cure and to improve survival. ${ }^{(2,3)}$ This kind of carcinoma presents metastasis and has a poor prognosis.

In the present article we report a case of a male patient with small cell carcinoma of the bladder and the development of the condition, and we aim to show the most current management of this tumor, which has no consensus for treatment in the international literature for being extremely rare.

\section{CASE REPORT}

Patient JHC, male, 61 years old, came to the medical service with a complaint of hematuria and hypogastric pain for one year. The urinary tract ultrasound revealed an intravesical tumor, and he was submitted to bladder TUR, with a conclusive report for small cell carcinoma of the bladder. Faced with the diagnosis, the attending team chose to perform chemotherapy (received four sessions of cisplatin, gemcitabine and paclitaxel) (Figure 1).

When referred to our service, he was submitted to thorax and abdomen computerized tomography (CT) that showed a $6.2 \times 6.0 \times 5.5 \mathrm{~cm}$ neoplasm on the left anterolateral wall of the bladder, suggesting invasion of the prostatic urethra. No lymph nodes were affected and there were no metastatic lesions at other sites.

\footnotetext{
1 Faculdade de Ciências Médicas, Santa Casa de São Paulo, São Paulo, SP, Brazil.

${ }^{2}$ Santa Casa de Misericórdia de São Paulo, São Paulo, SP, Brazil.

Corresponding author: Bruno Nagel Calado - Santa Casa de São Paulo, Rua Dr. Cesario Motta Jr, 112 - Vila Buarque - Zip code: $01221-020$ - São Paulo, SP, Brazil - Phone: (55 11) 2176-7000 E-mail: caladobnc@gmail.com

Received on: Oct 3, 2013 - Accepted on: Aug 18, 2014

DOI: 10.1590/S1679-45082014RC2975
} 
The patent was then submitted to radical cystectomy, with a Bricker ileal derivation procedure, performed uneventfully, lasting 5 hours, with no need for blood transfusion. It is important to underscore that the time between the last chemotherapy and surgery was 2 months.

The pathology report of the surgical specimen proved small cell carcinoma of the bladder with extravesical extension, perineural and vascular infiltration, and one lymph node affected (left obturator) out of 16 dissected. Free margins. Final staging T3bN1.

During the post-operative period, the patient had pneumonia, was on antibiotics and was discharged 29 days after surgery. There were no surgical events. He was referred to oncology to discuss adjuvant therapy which was not initiated, because the patient died 4 months after surgery due to pulmonary thromboembolism (Figure 2).

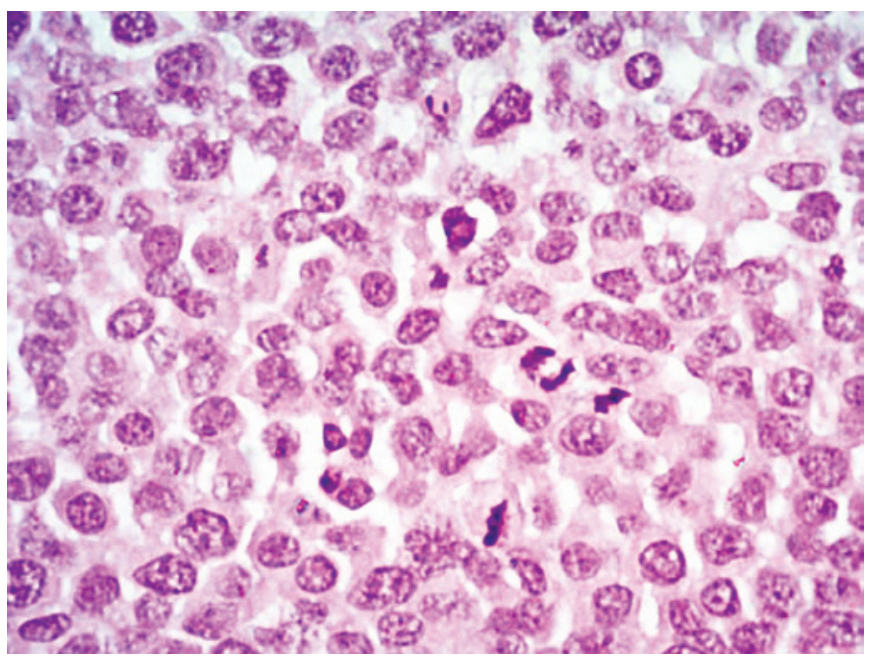

Figure 1. Field with the presence of multiple mitoses, salt-and-pepper nuclei

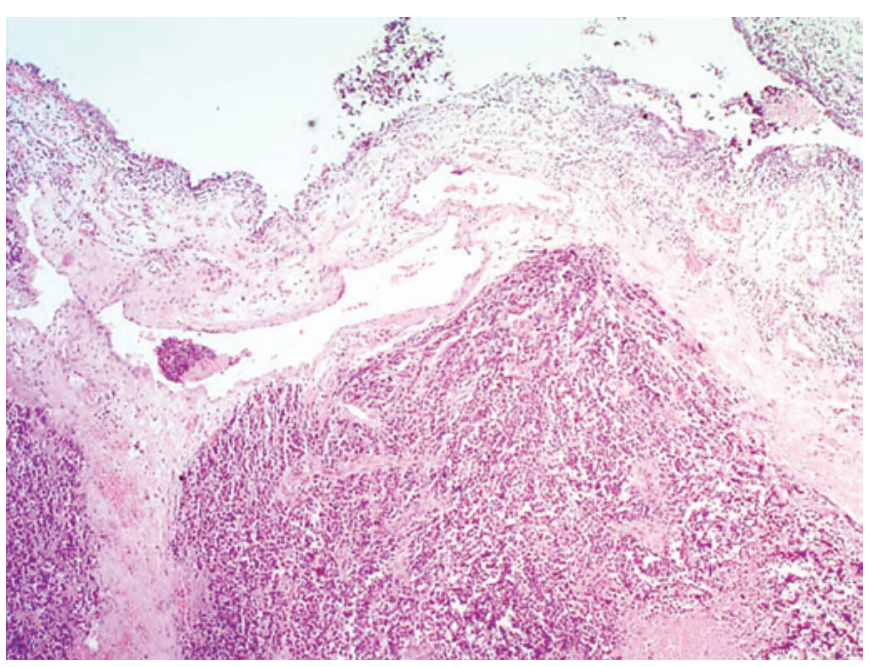

Figure 2. General overview of the tumor

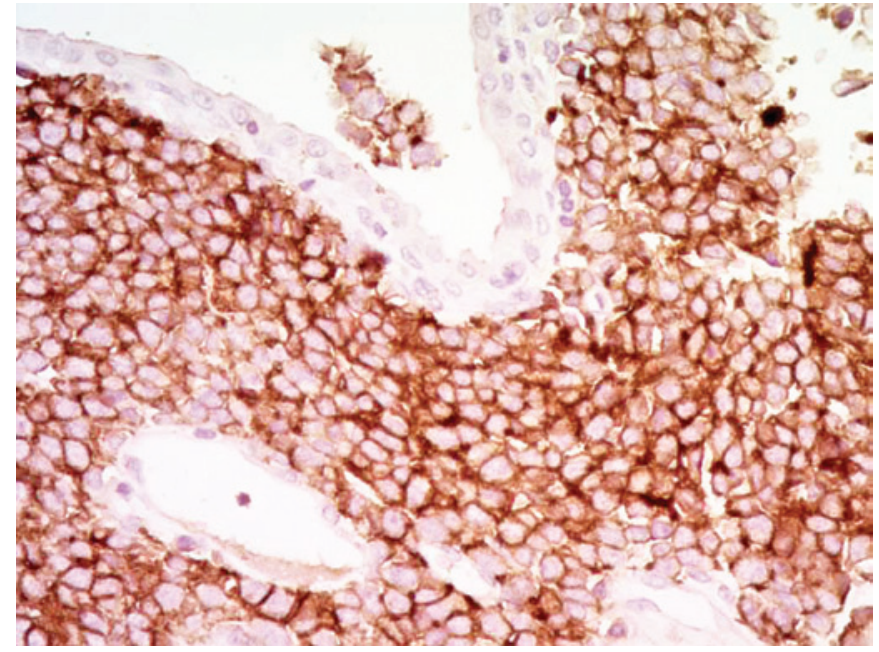

Figure 3. Marker CD-56 that characterizes neuroendocrine tumors

\section{DISCUSSION}

The first report of small cell carcinoma of the bladder was made in 1981 by Cramer et al. Since then, approximately 600 cases were registered in the international literature. ${ }^{(4)}$ It is characterized by its high aggressiveness and poor prognosis, and by the development of metastic disease in about $67 \%$ of patients. ${ }^{(3)}$

The small cell carcinoma of the bladder usually affects individuals of the same age, sex and presents the same symptoms and morphology of urothelial carcinoma. That is why it is a diagnostic challenge, depending only on the skills of the pathologist to differentiate it from urothelial carcinoma, which beside the factors already mentioned, has the same radiological aspect of small cell carcinoma of the bladder. There is no consensus as to treatment, because it is an uncommon condition. Thus, recommendations are based on retrospective studies, reports of individual cases, and protocols for small cell lung carcinoma.

Frequently, it presents with mixed histology.(5) Molecular studies show a common origin for small cell carcinoma of the bladder and urothelial carcinoma, when coexisting. However, management should be different, since it frequently presents metastases and has a poor prognosis. The pathological diagnosis of this kind of tumor is challenging and requires that the pathologist use immunohistochemical techniques for histological confirmation. As they are histologically identical, the World Health Organization standardization for small cell lung carcinoma is used. It comprises the following criteria for diagnosis of small cell carcinoma of the bladder: presence of group of small cells with scarce cytoplasm, few organelles, "salt and pepper" chromatin and high rate of mitoses ( $>10$ mitoses/10 high power fields). ${ }^{(4)}$ 
On immunohistochemistry, these tumors express quite an amount of neurospecific enolase, chromogranin, synaptophysin and N-CAM (CD-56). The presence of one or more markers allows to establish the diagnosis of neuroendocrine tumor. Pathological staging is based on the consensus for urothelial carcinoma of the bladder (Figure 3). ${ }^{(4)}$

Isolated therapies - whether TUR, partial cystectomy or radiation therapy - present benefit only in special cases of initial stage disease. Radical cystectomy is considered the best method to eliminate small cell carcinoma of the bladder completely, but it alone is believed to only change survival in stage I and II tumors. ${ }^{(3,6)}$ Cheng et al. reviewed 64 cases and concluded that in patients submitted to radical surgery compared to those treated with combined treatment (whether only chemotherapy or radiation therapy or both as adjuvant), there was no increase in survival. ${ }^{(7)}$ In contrast, chemotherapy adjuvant to radical cystectomy resulted in a favorable prognosis in other studies, including meta-analyses. ${ }^{(7,8)}$

Another alternative is neoadjuvant chemotherapy, recommended by the MD Anderson Cancer Center, which reported a 5-year disease free survival in $36 \%$ of the group submitted to radical cystectomy alone and of $78 \%$ in the group submitted to chemotherapy neoadjuvant to surgery. ${ }^{(9)}$ Similarly, neo adjuvant radiation therapy has also shown itself efficient.

On the other hand, a Canadian group reported ten patients with pT3-T4, N0 lesions with chemotherapy, attaining complete remission in nine of them. The 2-year survival rate for this group was $70 \%$ and, $44 \%$ in 5 years. (10) Another similar series reported four patients treated with chemotherapy followed by radiation therapy who survived 27 to 60 months. The advantage of this treatment is sparing the organ. Therefore, it is a less invasive treatment when compared to radical surgery, which is related to important rates of morbidity and mortality. ${ }^{(11)}$

Patients with metastatic disease should receive systematic chemotherapy, and the most common treatment regimens are platinum-based (cisplatin and etoposide, carboplatin, etoposide and cyclophosphamide) (Figure 2).(2)

\section{CONCLUSION}

Given the extremely aggressive and rare disease, little is known about pathogenesis and molecular biology. Data on the ideal approach for this kind of tumor are scarce, showing the importance of reporting such cases and, in this way, defining the best diagnostic and treatment methods.

\section{REFERENCES}

1. Zhao X, Flynn EA. Small cell carcinoma of the urinary bladder: a rare, aggressive neuroendocrine malignancy. Arch Pathol Lab Med. 2012;136(11):1451-9.

2. Shahab N. Extrapulmonary small cell carcinoma of the bladder. Semin Oncol. 2007;34(1):15-21.

3. Church DN, Bahl A. Clinical review - small cell carcinoma of the bladder. Cancer Treat Rev. 2006;32(8):588-93.

4. Cramer SF, Aikawa M, Cebelin M. Neurosecretory granules in small cell invasive carcinoma of the urinary bladder. Cancer. 1981;47(4):724-30.

5. Mazzucchelli R, Morichetti D, Lopez-Beltran A, Cheng L, Scarpelli M, Kirkali Z, et al. Neuroendocrine tumours of the urinary system and male genital organs: clinical significance. BJU Int. 2009;103(11):1464-70. Review.

6. Choong NW, Quevedo JF, Kaur JS. Small cell carcinoma of the urinary bladder. The Mayo Clinic experience. Cancer. 2005;103(6):1172-8.

7. Cheng L, Pan CX, Yang XJ, Lopez-Beltran A, MacLennan GT, Lin H, et al. Small cell carcinoma of the urinary bladder: a clinicopathologic analysis of 64 patients. Cancer. 2004;101(5):957-62.

8. Mackey JR, Au HJ, Hugh J, Venner P. Genitourinary small cell carcinoma: determination of clinical and therapeutic factors associated with survival. J Urol. 1998;159(5):1624-9.

9. Siefker-Radtke AO, Dinney CP, Abrahams NA, Moran C, Shen Y, Pisters LL, et al. Evidence supporting preoperative chemotherapy for small cell carcinoma of the bladder: a retrospective review of the M. D. Anderson cancer experience. J Urol. 2004;172(2):481-4.

10. Lohrisch C, Murray N, Pickles T, Sullivan L. Small cell carcinoma of the bladder: long term outcome with integrated chemoradiation. Cancer. 1999;86(11): 2346-52.

11. Bastús R, Caballero JM, González G, Borrat P, Casalots J, Gomez de Segura G, et al. Small cell carcinoma of the urinary bladder treated with chemotherapy and radiotherapy: results in five cases. Eur Urol. 1999;35(4):323-6. 